\title{
PENGARUH LINGKUNGAN KELAS TERHADAP PRESTASI BELAJAR PESERTA DIDIK MTS MA’ARIF NU O4 DESA KLADI KECAMATAN CERMEE BONDOWOSO
}

\author{
Lusy Endang Sri Darmawati ${ }^{1}$, Tutik Anggraeni ${ }^{2}$, Miftahus Surur ${ }^{3}$ \\ STKIP PGRI Situbondo, Indonesia \\ surur.miftah99@gmail.com
}

\begin{abstract}
Abstrak
Penelitian ini bertujuan untuk mengetahui ada tidaknya pengaruh lingkungan kelas terhadap prestasi belajar. Penelitian ini merupakan penelitian kuantitatif. Metode pengumpulan data menggunakan angket atau angket, dokumentasi dan observasi. Subjek penelitian adalah seluruh siswa MTs Ma'arif NU 04 desa Kladi dengan jumlah populasi 60 siswa. Analisis data meliputi korelasi dan variasi garis regresi. Uji hipotesis untuk mengetahui pengaruh lingkungan kelas terhadap prestasi belajar siswa dengan hasil $F$ hitung $=129,315, F$ tabel 3,16 pada $=0,05$ ternyata $F$ hitung $=129,315>$ f tabel 3,16 Kontribusi efektif (SE) prediktor (X_l) lingkungan fisik kelas dengan kriteria $(Y)$ prestasi belajar siswa 29.843,493\%. Kontribusi efektif ( $S E)$ prediktor ( $\left.X_{-} 2\right)$ lingkungan kelas non fisik terhadap prestasi belajar siswa 29,036\%, hal ini menunjukkan bahwa lingkungan kelas fisik dan non fisik berpengaruh terhadap prestasi belajar siswa. Dengan hasil data yang telah diuraikan sebelumnya dapat dikatakan bahwa "ada pengaruh lingkungan fisik dan non fisik kelas terhadap prestasi belajar siswa semester genap di MTs Ma'arif NU 04 desa talas di tahun ajaran 2020/2021.

Kata Kunci: Siswa, Lingkungan Kelas, Aktivitas Belajar
\end{abstract}

\begin{abstract}
This study aims to determine whether there is an effect of the classroom environment on learning achievement. This research is a quantitative research. Methods of data collection using questionnaires or questionnaires, documentation and observation. The research subjects were all students at MTs Ma'arif NU 04 Kladi village with a total population of 60 students. Data analysis includes correlation and variation of the regression line. Hypothesis testing to determine the effect of the classroom environment on student learning achievement with the results of $F$ count $=129,315, F$ table 3,16 at = 0,05 turns $F$ count $=129,315$ $>$ f table 3,16 Effective contribution $(S E)$ predictor $\left(X_{-} 1\right)$ environment physical class to the criterion $(Y)$ of student learning achievement 29.843.493\%. Effective contribution ( SE) predictor ( X_2) non-physical classroom environment on student learning achievement $29.036 \%$, this indicates that the physical and nonphysical classroom environment affects student learning achievement. With the results of the data that have been described previously, it can be said that "there is an influence of the physical and non-physical classroom environment on the learning achievement of even semester students at MTs Ma'arif NU 04 taro village in the 2020/2021 school year.
\end{abstract}

Keywords: Student, Classroom Environment, Learning Activity

Al Qalam: Jurnal Ilmiah Keagamaan dan Kemasyarakatan Vol. 16, No. 2

Maret - April 2022 
Lusy Endang Sri Darmawati, Tutik Anggraeni, Miftahus Surur : Pengaruh Lingkungan Kelas Terhadap Prestasi Belajar Peserta Didik MTs Ma'arif NU 04 Desa Kladi Kecamatan Cermee Bondowoso

\section{PENDAHULUAN}

Faktor pendukung terpenting penunjang kesuksesan belajar peserta didik ialah lingkungan kelas. Lingkungan kelas adalah segala sesuatu yang berhubungan dengan tempat proses pembelajaran dilaksanakan. Kelas merupakan taman belajar bagi peserta didik dan menjadi tempat mereka, bertumbuh dan berkembang baik secara fisik, intelektual maupun emosional. Oleh karena itu kelas harus dikelola sedemikian rupa sehingga benar-benar merupakan taman belajar yang menyenangkan. Menurut Latief, lingkungan sangat penting terhadap sebuah proses pendidikan terutama lingkungan kelas/sekolah. ${ }^{1}$ Baik buruknya lingkungan disekitar peserta didik merupakan faktor utama yang mempengaruhi perkembangan jiwa dan keberhasilan peserta belajar peserta didik. Lingkungan kelas tersebut dapat bersifat fisik dan non fisik, lingkungan kelas yang bersifat fisik misalnya ruang kelas, perabotan kelas, kebersihan kelas, dan lain-lain. Sedangkan lingkungan kelas yang bersifat non fisik berupa relasi guru dengan peserta didik, relasi peserta didik dengan peserta didik, kurikulum dll. ${ }^{2}$

Prestasi adalah kemampuan nyata yang merupakan hasil interaksi antara berbagai faktor yang memengaruhi baik dari dalam maupun dari luar individu dalam belajar. Prestasi diraih dari hasil keuletan kerja, dimana setiap orang mengejar prestasi menurut bidang dan kemampuan masing-masing. Prestasi dapat dikatakan sebagai suatu hasil yang telah dicapai seseorang sebagai bukti usaha yang telah dilakukan. ${ }^{3}$

Faktor-faktor yang mempengaruhi prestasi belajar ada dua golongan yakni faktor intern dan ekstern. Adapun faktor intern yaitu yang ada dalam diri individu yang sedang belajar, sedangkan faktor ekstern adalah faktor yang ada diluar individu.

1. Faktor intern

a. Kesehatan

b. Intelegensi dan bakat

1 Abdul Latief, "Pengaruh Lingkungan Sekolah Terhadap Hasil Belajar Pendidikan Kewarganegaraan Pada Peserta Didik Di SMK Negeri Paku Kecamatan Binuang Kabupaten Polewali Mandar," Jurnal Pepatuzdu 7, no. 1 (Mei 2014).

${ }^{2}$ Sardiman A.M (2009) interaksi dan motivasi belajar-mengajar, Jakarta: Rajawali pers. Lihat juga Slameto. 2003 Belajar dan Faktor-faktor yang mempengaruhinya. Jakarta: rineka cipta.

${ }^{3}$ Saputro, S.T,. dan pardiman 2012. Pengaruh disiplin belajar dan lingkungan teman sebaya terhadap prestasi belajar mahasiswa program studi pendidikan akutansi angkatan 2019 fakultas ekonomi universitasnegri Yogyakarta. Jurnal pendidikan akutansi Indonesia, X(1) hal.81-93. Lihat juga Indah susanti.(2012). Pengaruh lingkungan sekolah dan perhatian orang tua terhadap prestasi belajar akuntasui siswa kelasXI IPS MAN gandekan bantul tahun pellajaran 2011-2012./ skripsi. Universitas negeri Yogyakarta.

Al Qalam: Jurnal Ilmiah Keagamaan dan Kemasyarakatan Vol. 16, No. 2 Maret - April 2022 
Lusy Endang Sri Darmawati, Tutik Anggraeni, Miftahus Surur : Pengaruh Lingkungan Kelas Terhadap Prestasi Belajar Peserta Didik MTs Ma'arif NU 04 Desa Kladi Kecamatan Cermee Bondowoso
c. Minat dan motivasi
d. Cara brlajar

2. Faktor ekstern
a. Lingkungan keluarga
b. Lingkungan sekolah
c. Lingkungan masyarakat dan sosial

\section{METODE PENELITIAN}

Penelitian ini menggunakan pendekatan kuantitatif dan metode penelitian yang digunakan dalam rancangan Ex Post Facto.

Penelitian ex post facto adalah penelitian yang meliputi hubungan sebab akibat yang tidak dimanipulasi oleh peneliti. Adanya hubungan sebeb akibat didasarkan atas kajian teoritis, bahwa suatu variabel tertentu mengakibatkan variabel tertentu. ${ }^{4}$

Dalam penelitian ini untuk menentukan daerah penelitian menggunakan metode "Purposive Sampling Area" yaitu di MTs Ma'arif NU 04 Kladi kecamatan Careme Bondowoso. Hal ini dikarenakan sekolah memberikan ijin sekolahnya diteliti dan tempatnya terjangkau.

Teknik pengumpulan data menggunakan angket atau kuesioner, dokumentasi dan observasi. Untuk mengetahui seberapa besar atau kecil pengaruh Variabel X terhadap Variabel Y, maka teknik analisis data dengan menggunakan uji validitas dan analisis regresi.

\section{Uji Validitas}

Uji validitas dari suatu pertanyaan yang digunakan dalam pengumpulan data dengan cara mengkorelasikan setiap nilai variabel jawaban dari responden dengan jumlah nilai di setiap variabel. Maka selanjutnya nilai dari korelasi dibandingkan dengan nilai kritis signifikan 0,05 . Adapun rumus uji validitas sebagai berikut:

$$
r_{x y}=\frac{n \sum x y-\left(\sum x\right)\left(\sum y\right)}{\sqrt{n\left[\sum x^{2}-\left(\sum x\right)^{2}\right]\left[n\left[\sum y^{2}-\left(\sum y\right)^{2}\right]\right.}}
$$

\footnotetext{
${ }^{4}$ Emzir, Metodologi Penelitian Pendidikan Kuantitatif \& Kualitatif (Jakarta: PT.
} Raja Grafindo Persada, 2013), 42. Lihat juga Sugiono (2013). Metode penelitian pendidikan kuantitatif,kualitatif, dan $R \& D$. bandung:CV alfabeta. Lihat juga Sugiyono. ( 2007 ) Statistika Untuk penelitian. Bandung: alfabeta. Lihat juga Setyosari, pujana M. E. (2013). Metode Penelitian Pendidikan \& Pengembangan_nodrm.pdf.

Al Qalam: Jurnal Ilmiah Keagamaan dan Kemasyarakatan Vol. 16, No. 2

Maret - April 2022 
Lusy Endang Sri Darmawati, Tutik Anggraeni, Miftahus Surur : Pengaruh Lingkungan Kelas Terhadap Prestasi Belajar Peserta Didik MTs Ma’arif NU 04 Desa Kladi Kecamatan Cermee Bondowoso

Keterangan:

$\mathrm{r}_{\mathrm{xy}}=$ Koefisien korelasi

$x=$ Skor pertanyaan tiap nomor

$y=$ Jumlah skor total pertanyaan

$n=$ Jumlah responden

\section{Analisis Regresi}

Dalam pengujian ini peneliti menggunakan analisis regresi sederhana,yakni dengan rumus sebagai berikut:

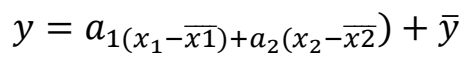

\section{a. Menghitung Koefisien Korelasi}

Menghitung koefisien korelasi berganda atau timgkat hubungan antara variabel terikat dengan variabel bebas dengan menggunakan rumus:

$$
\operatorname{Ry}(1,2,) \sqrt{\frac{a 1 \sum x 1 y+a 2 \sum x 2 y}{\sum y 2}}
$$

b. Menghitung Analisis Varian Garis Regresi(Freg)

Setelah diketahui koefisien korelasi kemudian dicari nilai Freg Untuk mengetahui apakah Ry $(1,2,3)$ signifikan atau tidaknya nilai yang diperoleh antara dua variabel, yaitu dengan rumus:

$$
\mathrm{F} \text { reg }=\frac{\mathrm{R}^{2}(n-m-1)}{\mathrm{m}\left(1-\mathrm{R}^{2}\right)}
$$

Keterangan:

$R^{2} \quad=$ nilai $\mathrm{Ry}(1,2)$ dikuadratkan

$\mathrm{N} \quad=$ banyaknya responden

$\mathrm{M} \quad$ = banyaknya variabel bebas

\section{c. Efektifitas Garis Regresi}

EGR digunakan jika peneliti ingin informasi mengenai sumbangan relatif tiap predictor dari keseluruhan dengan rumus:

EGR $=\frac{\text { JKreg }}{\text { JKtot }} \times 100 \%$

Al Qalam: Jurnal Ilmiah Keagamaan dan Kemasyarakatan Vol. 16, No. 2

Maret - April 2022 
Lusy Endang Sri Darmawati, Tutik Anggraeni, Miftahus Surur : Pengaruh Lingkungan Kelas Terhadap Prestasi Belajar Peserta Didik MTs Ma'arif NU 04 Desa Kladi Kecamatan Cermee Bondowoso

\section{d. Sumbangan Efektif (SE)}

Sumbangan efektif adalah sumbangan prediktor yang dihitung dari keseluruhan efektifitas regresi hal ini peneliti ingin mengetahui sumbangan efektifitas tiap prediktor dari keseluruhan prediksi, maka SE\% tiap predictor harus dihitung dari persentase efektifitas garis regresi yaitu:

$$
\text { SE } \% x_{1}=\frac{a_{1} \sum \mathrm{x}_{1} \mathrm{y}}{\mathrm{JKreg}} \mathrm{X} \text { EGR }
$$

$$
\mathrm{SE}_{2} \% x_{2}=\frac{\mathrm{A}_{2} \sum \mathrm{x}_{2} \mathrm{y}}{\mathrm{JKreg}} \quad \mathrm{X} \text { EGR }
$$

\section{HASIL DAN PEMBAHASAN}

1. Hasil Uji Validitas

Uji validitas merupakan uji dari suatu pertanyaan yang digunakan dalam pengumpulan data-data dengan cara mengkorelasikan setiap nilai variabel, yang kemudian dibandingkan dengan nilai kritis signifikan $0,05 \%$. Adapun hasil dari uji validitas yang telah dilakukan.

\begin{tabular}{|c|c|c|c|}
\hline $\begin{array}{l}\text { No } \\
\text { item }\end{array}$ & R hitung & r tabel & Uji validitas \\
\hline 1 & 0.522 & 0,254 & Valid \\
\hline 2 & 0.642 & 0,254 & Valid \\
\hline 3 & 0.958 & 0,254 & Valid \\
\hline 4 & 0.550 & 0,254 & Valid \\
\hline 5 & 0.608 & 0,254 & Valid \\
\hline 6 & 0.916 & 0,254 & Valid \\
\hline 7 & 0.737 & 0,254 & Valid \\
\hline
\end{tabular}

Keterangan:

a. Jika $r$ hitung $>\mathrm{r}$ tabel, maka item angket dinyatakan valid. Dan sebaliknya, jika $\mathrm{r}$ hitung < r tabel, maka item angkrt dinyatakan tidak valid .

Al Qalam: Jurnal Ilmiah Keagamaan dan Kemasyarakatan Vol. 16, No. 2

Maret - April 2022 
Lusy Endang Sri Darmawati, Tutik Anggraeni, Miftahus Surur : Pengaruh Lingkungan Kelas Terhadap Prestasi Belajar Peserta Didik MTs Ma’arif NU 04 Desa Kladi Kecamatan Cermee Bondowoso

b. R tabel diperoleh dari tabel koefisien korelasi dengan taraf signifikan ( $\alpha$ ) $5 \%$ serta derajat bebas $(\mathrm{db})=\mathrm{n}-2$ dimana $\mathrm{n}$ adalah jumlah responden yaitu 60-2 $=58$

c. 0.254 adalah nilai $r$ tabel dengan tingkat signifikan 0,005 sedangkan 0 , adalah nilai $r$ tabel dengan tingkat signifikan 0,01 .

\section{A. Pengaruh lingkungan kelas terhdap prestasi belajar peserta didik}

\section{Persamaan Garis Regresi}

\section{a. Konstanta}

konstanta sebesar 45,507 mempunyai arti adanya pengaruh yang positif terhadap prestasi belajar peserta didik semester ganjil tahun pelajaran 2020/2021 yaitu lingkungan kelas yang bersifat fisik dan non fisik tetap atau konstan akan mempengaruhi prestasi belajar peserta didik sebesar 45,507 dengan variabel penganggu yang tidak diteliti.

\section{b. Koefisien Regresi Lingkungan Kelas Yang Bersifat Fisik}

koefisien regresi lingkungan kelas yang bersifat fisik ( $X_{1}$ ) menunjukkan besarnya perubaha $\mathrm{X}_{1}$ terhadap $\mathrm{Y}$ perubahan tersebut bersifat positif atau searah, artinya apabila salah satu variabel mengalami kenaikan, akan mengakibatkan kenaikan pada variabel lain. Apabila terjadi perubahan variabel lingkungan kelas yang bersifat fisik sebesar $1 \%$ dengan anggapan variabel lingkungan kelas yang bersifat non fisik $\left(\mathrm{X}_{2}\right)$ sama dengan nol, menyebabkan perubahan variabel prestasi belajar (Y) sebesar 0,784

\section{c. Koefisien Regresi Lingkungan Kelas Yang Bersifat non Fisik}

koefisien Regresi Lingkungan kelas yang bersifat non fisik $\left(\mathrm{X}_{2}\right)$ menunjukkan besarnya perubaha $\mathrm{X}_{1}$ terhadap $\mathrm{Y}$ perubahan tersebut bersifat positif atau searah, artinya apabila salah satu variabel mengalami kenaikan, akan mengakibatkan kenaikan pada variabel lain. . Apabila terjadi perubahan variabel lingkungan kelas yang bersifat fisik sebesar 1\% dengan anggapan variabel lingkungan kelas yang bersifat fisik $\left(\mathrm{X}_{1}\right)$ sama dengan nol, menyebabkan perubahan variabel prestasi belajar (Y) sebesar 0,885

\section{b. Menghitung Kkoefisien korelasi antara Variabel Bebas $\left(X_{1}\right.$ dan $\left.X_{2}\right)$ Dengan Variabel}

\section{Terikat (Y)}

Dari hasil penelitian yang diperoleh dengan menggunakan rumus analisis varian garis regresi menghasilkan Ry $(1,2)$ sebesar 0,905 . Yang apabila dikonsultasikan dengan $r$ tabel dengan $\mathrm{N}$ sebanyak 60 responden dan taraf signifikan 5\% diperoleh 0,254 perhitungan

Al Qalam: Jurnal Ilmiah Keagamaan dan Kemasyarakatan Vol. 16, No. 2

Maret - April 2022 
Lusy Endang Sri Darmawati, Tutik Anggraeni, Miftahus Surur : Pengaruh Lingkungan Kelas Terhadap Prestasi Belajar Peserta Didik MTs Ma'arif NU 04 Desa Kladi Kecamatan Cermee Bondowoso

tersebut dimaksudkan untuk membuktikan hipotesa kerja mayor dengan menggunakan uji signifikan

\section{c. Varian Garis Regresi}

Dari hasil perhitungan analisis varian garis regresi diperoleh Freg sebesar 129,315. Dan apabila di konsultasikan dengan $\mathrm{f}$ tabel untuk $\mathrm{db}=2$ dan sebesar 58 dengan taraf signifikan 5\% diperoleh 3.16. Dengan demikian dari hasil perhitungan tersebut menunjukan Freg lebih besar dari $\mathrm{F}$ tabel yang berarti signifikan secara mayor lingkungan kelas terhadap prestasi belajar.

\section{d. Efektifitas Garis Regresi}

Dalam efektifitas garis regresi diperoleh 29,28\% / 29,3\% yang merupakan sumbangan efektif dari prediktor prestasi belajar peserta didik. Sedangkan prediktor lain yang tidak diteliti baik dari faktor intern atau ekstern lainnya meliputi bakat, lingkungan keluarga, lingkungan sosial masyarakat dan lingkungan sekitar diperoleh nilai 70,7\% .

\section{KESIMPULAN}

Berdasarkan hasil penelitian dan uraian diatas, maka dapat disimpulkan bahwa Ada pengaruh singnifikan nilai koefisien korelasi sempurna sebesar 0,905 Untuk mengetahui sejauh mana pengaruh antara lingkungan kelas yang bersifat fisik dan non fisik terhadap prestasi belajar peserta didik semester ganjil di MTs Ma'arif NU 04 tahun pelajaran 2020/2021.

\section{DAFTAR PUSTAKA}

Emzir. Metodologi Penelitian Pendidikan Kuantitatif \& Kualitatif. Jakarta: PT. Raja Grafindo Persada, 2013.

Latief, Abdul. "Pengaruh Lingkungan Sekolah Terhadap Hasil Belajar Pendidikan Kewarganegaraan Pada Peserta Didik Di SMK Negeri Paku Kecamatan Binuang Kabupaten Polewali Mandar.” Jurnal Pepatuzdu 7, no. 1 (Mei 2014).

Setyosari, pujana M. E. (2013). Metode Penelitian Pendidikan \& Pengembangan_nodrm.pdf.

Saputro, S.T, . dan pardiman 2012. Pengaruh disiplin belajar dan lingkungan teman sebaya terhadap prestasi belajar mahasiswa program studi pendidikan akutansi angkatan 2019 fakultas ekonomi universitasnegri Yogyakarta. Jurnal pendidikan akutansi Indonesia, $\mathrm{X}(1)$ hal.81-93

Sardiman A.M (2009) interaksi dan motivasi belajar-mengajar, Jakarta: Rajawali pers

Slameto. 2003 Belajar dan Faktor-faktor yang mempengaruhinya. Jakarta: rineka cipta.

Sugiyono. ( 2007 ) Statistika Untuk penelitian. Bandung: alfabeta

Al Qalam: Jurnal Ilmiah Keagamaan dan Kemasyarakatan Vol. 16, No. 2

Maret - April 2022 
Lusy Endang Sri Darmawati, Tutik Anggraeni, Miftahus Surur : Pengaruh Lingkungan Kelas Terhadap Prestasi Belajar Peserta Didik MTs Ma’arif NU 04 Desa Kladi Kecamatan Cermee Bondowoso

Sugiono (2013). Metode penelitian pendidikan kuantitatif,kualitatif, dan $R \& D$. bandung:CV alfabeta

Indah susanti.(2012). Pengaruh lingkungan sekolah dan perhatian orang tua terhadap prestasi belajar akuntasui siswa kelasXI IPS MAN gandekan bantul tahun pellajaran 2011-2012./ skripsi. Universitas negeri Yogyakarta.

Al Qalam: Jurnal Ilmiah Keagamaan dan Kemasyarakatan Vol. 16, No. 2

Maret - April 2022 